\title{
Leveraging on Digital Technologies to Up-Scale Tourism for Economic Growth in Africa
}

\author{
John E. Efiong, Wesley University, Ondo, Nigeria \\ https://orcid.org/0000-0003-4391-2475 \\ Adewale S. Adegbola, Wesley University, Ondo, Nigeria
}

\begin{abstract}
The application of digital technologies in various human endeavours today is unabated. This article presents information and communications technologies (ICTs) as a driving force for promoting tourism in Africa for accelerated economic growth. Descriptive methodology was used in the study. The study relied on the explored impacts of tourism on socio-economic development of the developing nations of Africa and encourages the adoption of persona models in implementing technological strategies geared toward the promotion of tourism products and services on the continent. The article advocates technology compliance by all tourism organizations and involvement of all stakeholders, agencies of governments and ICT drivers in making Africa a destination of choice to the world by adopting appropriate technological provisions.
\end{abstract}

\section{KEYWORDS}

Africa, Economic Growth, ICT, Tourism, Tours And Trips

\section{INTRODUCTION}

Tourism is a sector that has remained relevant over time in the world's history. Due to its attractive nature, tourism has not only drawn many visitors but also supports the growth of the economies of continents that have identified and aligned with its inherent economic benefits. In the year 2013, the World Bank reported that the tourism industry in the sub-Saharan Africa would spur more economic growth for the area and proudly employ 6.7 million people by 2021 (World Bank, 2013). Furthermore, the World Travel and Tourism Council reported in the same year that:

the tourism sector is directly and indirectly responsible for 8.8 percent of the world's jobs (258 million); 9.1 percent of the world's Gross Domestic Product (GDP) (US\$6 trillion); 5.8 percent of the world's exports (US\$1.1 trillion); and 4.5 percent of the world's investment (US\$652 billion). It is estimated that 3.8 million jobs (including 2.4 million indirect jobs) could be created by the tourism industry in sub-Saharan Africa (SSA) over the next 10 years (World Bank, Africa House, \& ATA, 2010; WTTC, 2013).

This presented an amazing future for the SSA with effect from 2013. Africa has a rich ecosystem, not only for human habitation but also for tourism. The vast landmass, large water bodies, and numerous natural resources in the continent provide exciting platforms and sites for tourists attraction across the land. Some of these interesting sites found in different countries of the continent include waterfalls, 
beaches, game reserves, aquariums, rainforests, Wildlife, lakes, scenic beauty, natural habitats, natural meal cuisines, cultural heritage, etc. There are also some man-made or human-enhanced collections of beautiful sight like arts galleries, museum of natural histories and wars, potteries centres, resorts, international hotels, recreation parks, etc. (Itumo, 2017).

In the developed world, tourism enhances economic growth by helping generate a substantial income earned through foreign exchanges (World Bank-AFTFP, 2011). This is obviously not the case in Africa. Although Africa is blessed with huge potentials, the tourism opportunities are yet to be optimally utilized to support sustainable development. Sadly, the natural tourist centers that abound in the continent are largely not discovered and so remain unknown to the rest of the world who would need them for recreational, educational, or religious purposes. Due to the apparent hidden nature of these resources, therefore, they have become untapped and their potentials unharnessed. This implies wasting away what should ultimately generate revenues for the continent.

As we approach the predicted year 2023, how close are we to the reality? Africa would be able to meet this target and exceed its expectation with huge supports from its stakeholders, policy makers, investors and strategic planners and leveraging on computing technologies, which define the new way of doing things today.

The rest of the paper is structured as follows: Section 2 discusses related works in ICT adoption for tourism promotion in Africa and concepts bordering on smart tourism and digital marketing as a collection of tools for developing the travels and tours sector in Africa are explored. A brief analysis on the personas model as applicable to the sub-Saharan African scenario is performed. Section 3 discusses digital avalanche for tourism promotion in Africa. Here, the recent digital tools and options are enumerated and applied to African peculiar environment. The benefits of leveraging on ICT for tourism promotion in the continent are presented in Section 4 and the conclusion is drawn in Section 5.

\section{ICT ADOPTION IN THE AFRICAN TOURISM INDUSTRY}

From when the ICT found its way into the society, it has continuously penetrated deeply and permeates every facet of the human life. Today, there is hardly an identified area in the society where digital technologies have not gained access into and have not in real terms transformed. ICT has the propensity to transform any area where it is applied. In this paper, we argue that ICT can help tourism boost the economic purse of Africa.

Studies by Iain et al. (2016) and Itumo (2017) have shown the possibilities of Africa's economy significantly improving through tourism. However, these can only become a reality with strategic plans and structured modalities to make the tourist sites in the continent visible and attractive to the prospective tourists. This can be accomplished in a variety of ways, typically through aggressive promotion. In marketing, advertising and products promotion are key tools that must be given due attention if a firm is to remain in business. Since every product requires an adequate exposure for increased patronage, the tourism industry in Africa cannot but adopt adequate techniques to showcase its blessings to the rest of the world.

Previous studies on tourism in Africa had focused on the developmental rates across countries in the continent (Martín et al., 2017). Others were interested in estimating and forecasting the demand for tourism and probable income that can be or has been generated through the multiplier process. All of these studies leave a lacuna in the area of tourism promotion in the sub-saharan African region for which this paper attempts to address using computing privileges as the tool.

The present-day availability of digital tools and avenues provides the opportunities for announcing to the world the blessings of God in the region. ICTs grant us the ability to take a glance at a tourist site before actually planning a trip. Websites such as Yelp, TripAdvisor and other online travel research sites make it easier for one to digitally explore places and have a digital experience of those places before thinking of an adventure there. 
Guillermo Mazier of Atlas, as reported by Forbes Agency Council enumerates four digital techniques through which marketers can promote tourists attraction centers for increased traffic (Mazier, 2017). These include developing digital strategies, adopting search engine marketing, using mappable databases and using mobile applications. Mazier argues that digital strategies should be tailor-made to meet the needs of specific audiences. In other word, there must be a target and the tools and techniques must catch their attention at the very least on a short term. As a direct follow-up on the above, adopting search engine marketing where digital profiling techniques are used will help point online users to sites that meet their frequently searched contents. As users search the web, search engines gather their profiles and can make suggestions of what they would like to search for in the next search opportunities. This technique can allow managers of tourists sites and digital marketers to send details of tourism locations to the users. The task of mappable databases is to gather important facts of tourist sites in a central store - typically databases. These facts may cover history, direction, cost, management, buildings, properties and the most interesting points of attraction such that they provide a one-stop view of what the places offer. Such information can be presented to the users via mobile applications that run on their handheld devices.

\subsection{Smart Tourism}

Recent research assessing ICT invasion in tourism has seen to the evolution of a new terminology, called smart tourism. This is to allude to the emergence of paradigms in other areas of life, where we now have smart agriculture, smart transport, smart healthcare, smart law, smart security and surveillance, etc. The 'smartness' in these areas define the ubiquitous tendency of mobile technology which is a technology of anywhere and anytime. The attempt is to make our cities digital, hence the name "smart cities." Jasrotia and Gangotia (2018) submit that smart tourism is an integral and fundamental part of smart cities. This implies that in making a city smart, we are making it so for tourism purposes.

Gretzel, Zhong \& Koo (2016) assessed the possibility of applying smart devices such as smartphones, networked services, internet services, big data, sensors, and by extension virtually all components of the digital community to make tourism in cities a scintillating experience. Koo et al. (2015) did a similar exploration where the beauty of ICT in tourism was presented, specially geared towards social development. This situation is what scholars describe as smart tourism in cities. Smart tourism involves innovatively utilizing digital opportunities, especially mobile technologies to support tourists' experiences at sites. This capability largely depends on the rapidly developing trends such as internet of things, cloud computing, big data analytics, artificial intelligence, geospatial functionalities, etc. (Buhalis \& Amaranggana, 2014; Guo, Liu, \& Chai, 2014; Wang, Park, \& Fesenmaier, 2012).

Li et al. (2017) posit that smart tourism should only be said to exist where there is a tourist support system within the defined parameters of information service and its dependent technology. Buhalis and Amaranggana (2014) associate smart tourism with smart destinations, describing smart cities as smart destinations where the overall means of tour in the destinations are digitized. This digitization in a narrowed sense is the infusion of several functions into a mobile device or other smart tools. Gretzel et al. (2015) opined that smart tourism should give smart experience, have smart business ecosystem in a smart destination as shown in Figure 1. These would largely depend on the availability of data that are to be captured, processed and exchanged digitally with the assistance of smart tools. Where this occurs, smart tourism can be said to have been initiated.

\subsection{Digital Marketing Strategies for Upscaling Tourism}

Digital marketing (DM) involves all techniques, tricks, strategies, and tools employed to market a product or service empowered by technology. This is done by digitizing the contents or information of and about the commodity for mobile carriage (Jacob, 2018). DM uses photos, texts, audio and videos to present a commodity. The basic toolbox of the DM represented in Figure 2 contains social 


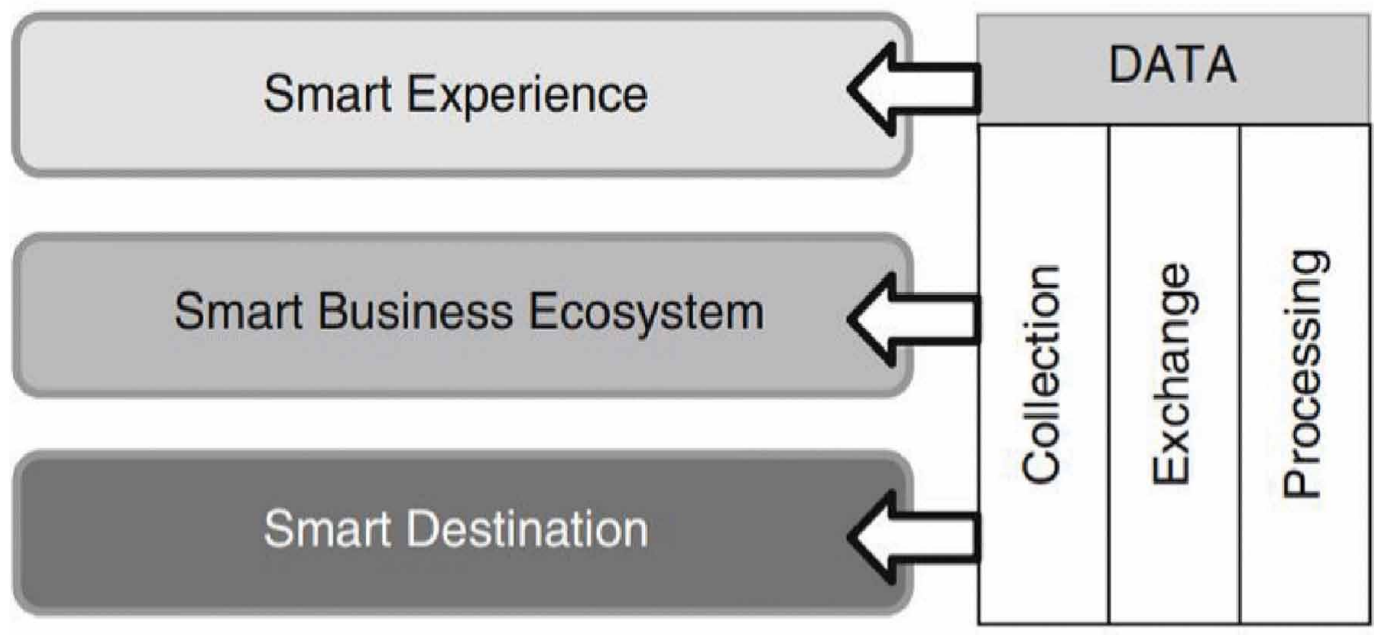

marketing, email marketing, SMS marketing, and blogging. These are just platforms and means through which the developed contents of DM can be distributed and shared to the prospective customers to create a first level awareness and remote impression of the tour sites and/or allow follow-up for continuous patronage. The pervasive effects of the digital waves are felt in every thinkable area of human participation. The tourism sector is currently feeling the breeze in a deepset sense. Travels and tours organizations in developed nations have leveraged on digital marketing strategies to grow their business.

Having realized the full essence of DM, the Ministry of Economy of the United Arab Emirates sponsors an annual executive training programme on digital marketing with the aim of equipping participants with knowledge, skills, tools, best practices, and a common platform for brainstorming on current trends in DM strategies and their implementation (UNWTO, 2017). In Africa, in order to fully understand and derive the positive results of DM for tourism promotion, there must first be an alignment with the potentials. We must align with best practices in the development of tourism in the $21^{\text {st }}$ century like Sri Lanka which has been repeatedly rated as a choice place for tourism in the world. How did they get to generate so much ripples? Certainly, a lot of hard work and strategy. According to Dissanayakelage (2013), while there are several factors that have played out to yield these amazing results, Sri Lanka gives adequate attention to DM as an imagemaker of its tourism industry. A peep into Sri Lanka' tourism website (http://www.srilanka.travels/) shows a compelling content, selling the goodness of the land at a glance. Furthermore, visitors to the web address get information and tour guides before even making up their minds to travel.

To show sufficient interest in DM toolbox, Sri Lanka operates its DM with a-seven phase digital framework shown in Figure 3.

According to Godwin (2009), the seven-step travel process is driven by digital technologies. A prospective visitor to Sri Lanka is first inspired by a testimony of an old visitor or by word-ofmouth of someone in the business. The visitor checks this out by performing a research to ascertain the claims. On conviction, the visitor plans a visit, validates plan, and then books for the adventure. Travel is made to Sri Lanka, and as the experience becomes scintillating; the visitor shares the story and inspires another prospective visitor. This cycle repeats itself in a natural process aided by the availability of the toolbox of DM. Thus, ICT becomes a strong driving force in the travels story. 
Figure 2. Digital marketing toolbox

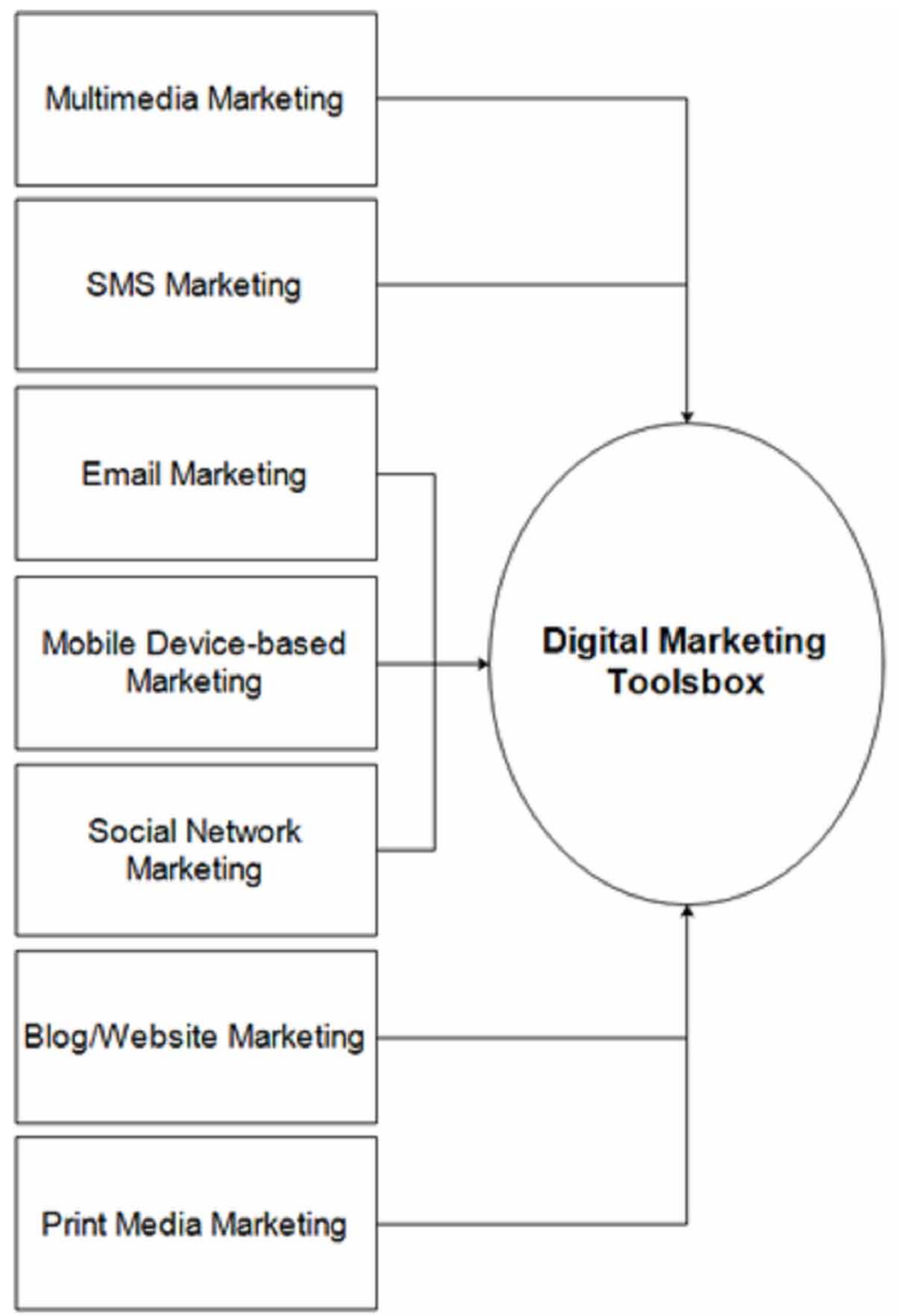

\subsubsection{The Personas Model}

The persona model is a digital marketing strategy where products and services are developed to meet the buying behaviours of a fictitious customer. As observed by Pruitt \& Adlin (2006), the trick of the persona model is to model the character of a person towards a product or service. Digital technologies make this modelling both fun and rewarding since the concept of persona evolved from a software development process (Godwin, 2009). Persona modelling is a user-centric or customercentered design model that incorporates the goals, desires, and limitations of prospective customers. The aim is to simulate the reactions of buyers about a service or product. Persona modelling is key in advertisement or product promotion.

The Tourism organizations in Africa will need to see the resources available in the continents as products that require aggressive promotion and then adopt appropriate techniques to model the 


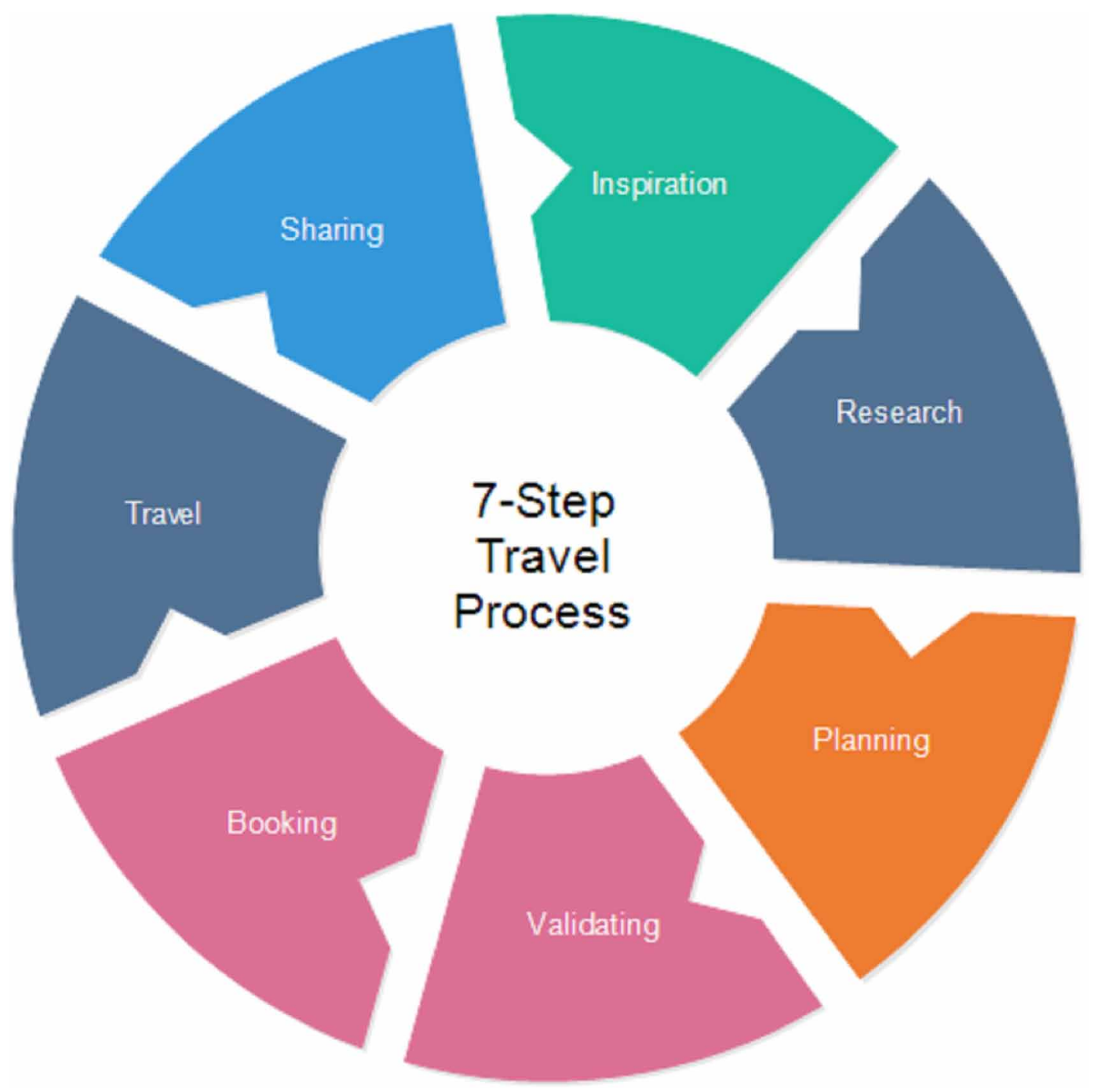

behaviours of the prospective tourists. By having the customers in mind, persona modelling can be a useful methodology for promoting these services and products. The essence of this will be to convince the customers when they eventually have access to the resources. By obtaining data about them, tourism development experts will need to bring humanity into the abstract data to represent the visitors. While some experts such as Nielsen (2013) argue that there is a difference between simulated customers' experience of a product and the real contact, persona modelling still helps achieve a far better result than not having done one at all. It is not out of place to model personas according to the respective market segments of the customers. This does not only help put customers in perspectives but also helps meet the classified needs of the target segments. 


\section{DIGITAL AVALANCHE FOR TOURISM PROMOTION IN AFRICA}

With the rapid growth of digital infrastructure and proliferation of smart devices as they aggressively penetrate sub-Saharan Africa, leveraging on ICTs for enhanced economic growth in the continent through the tourism industry is more than a necessity. As explored from the foregone sections, the opportunities are multifaceted and the choice is ours to make. Tourism in Africa can be up-scaled via six major digital tools, which are contents marketing software tools, digital marketing strategies, smart tourism, social media, user-centric web contents, and ICT policies as shown in Figure 4. The ergonometric and adoption of these tools should take into cognizance the personas model where the characteristic behaviours of the tourists are captured, simulated and integrated at the conception phase.

\subsection{Digital Marketing Strategies and Involvement}

African governments must support the development of digital marketing strategies that would favour tourism. In addition to DM toolbox earlier discussed and presented in Figure 2, the continent's interest in tourism development through DM should be reflected in governments' budgets, policies, regulations, and human capacity building. This is what our study calls digital marketing involvement (DMI). We believe the process should involve all stakeholders in the travels and tours industry, players in ICT design and implementation and relevant agents of government.

\subsection{Contents Marketing Software}

Contents marketing software (CMS) tools are programs that enable tourism organizations to create, manage and distribute visual contents about attraction centers they are trying to get patronage for. These contents can be shared on a plethora of online platforms and channels like social media, websites, and newsgroups to win as many customers as possible to the real locations. Some of the CMS are fliphtml5, Wideo, Codefuel, Outbrain, Uberflip, Scribblelive, Anyflip, Clearvoice, etc.

Fliphtml5 is a free digital content creator that allows developers to convert static Portable Data Format files, Microsoft Office documents and images to HTML5 page turning publications. This implies that travel related files could be transformed into digital visual and impressive pages (CMS, 2018). Besides, fliphtml5 allows beautiful animations, videos, audios, photo slideshow, links, bookmark, and flexible user-centric customization options. In addition to the cool features above, text contents describing the tourist sites can be easily crawled by search engines to increase visibility of sites. Another important CMS creator is the video, which is a video creator that can enable scintillating travel videos to be created for marketing campaigns. Since people believe more in what they see than what they read, video makes users' simulated experience look real.

Codefuel on the other end enables the combination of text, image, motions and tags into an amazing video content. Codefuel has attractive layouts to choose from in order to make an appealing video for tourism promotion. Outbrain is a high quality program that allows building of blogs, publishing of articles, creation of videos, infographics etc. This tool can be used to promote tourism in the SSA where technology is rapidly penetrating. Uberflip functions much in the same pattern as the Outbrain but the themes are powerful and can allow developers make user-friendly contents for tourism. The aim of Scribblelive is to allow travel stories and experiences about places to be shared in a fascinating manner such that prospective tourists would always want to go there. The amazing feature in Anyflip is its ability to use google analytics to obtain people's information and share travel publications with them. Finally, in that category is Clearvoice, which is simple to use to create travel contents and publish details about tourist attraction centers.

\subsection{Smart Tour Services}

As Koo et al. (2015) noted, a smart city is a smart destination. A smart destination requires sufficient and effective smart services. If our vision as a continent is to make Africa a smart tour destination, the development of smart services is inevitable. In reality, what make a smart city are the products 


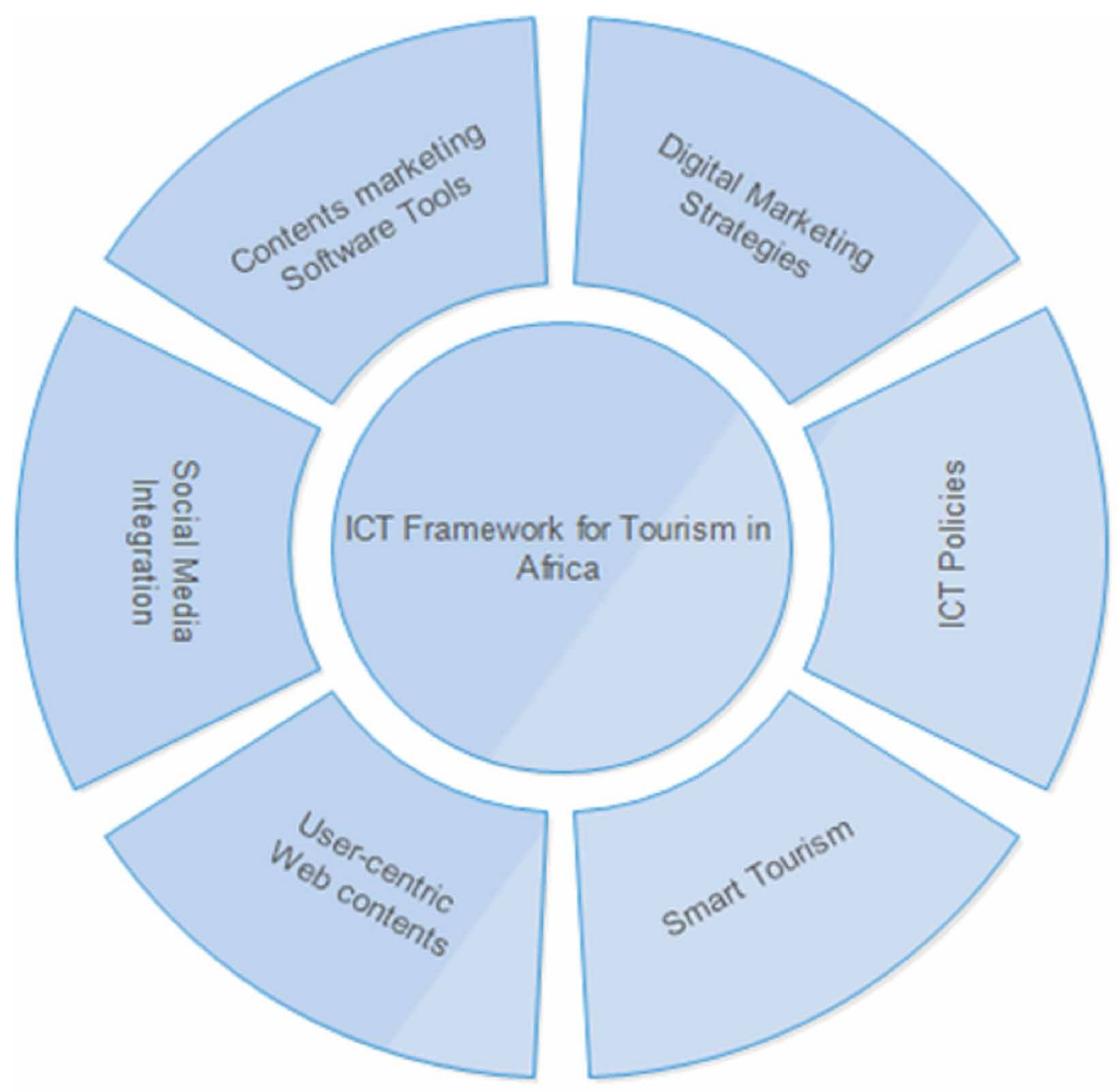

and services available, and the workforce and infrastructure that support the services. Africans are ever ready to learn and have ready minds to understand new concepts. The continent is mentally prepared to learn the smartness of the world in upscaling its tourism provisions for economic growth. Development of smart tour services is a job that can be handled internally if given the right supports from appropriate bodies. These services, as captured in Figure 5, will include elements such as smart tour guides in multimedia format to meet varying physiological deficiencies of tourists; tour hotlines which should be ready and dedicated phone lines to connect tourists. They can also be tourist smart stores, which should be a one-stop grocery store within tour centers, smart site security for surveillance, monitoring, and security checks and destination management support systems for geolocation guidance, wayfinding, and destination supports.

\subsection{User-centric Websites}

The principles of human computer interaction that deal with user-friendliness, simplicity, interactivity, and functionality must be adopted when developing websites for promoting tourism in Africa 

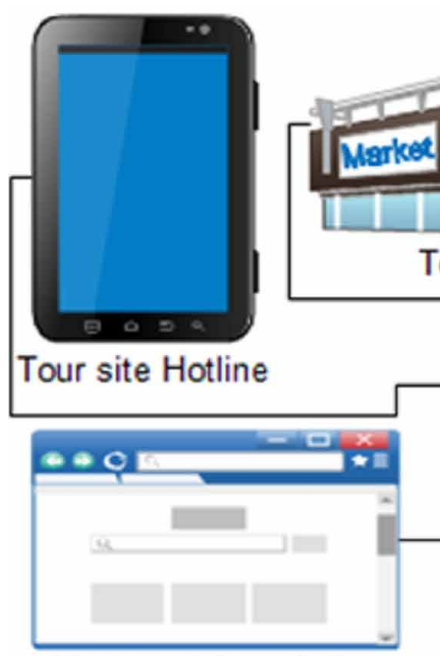

User-centric website

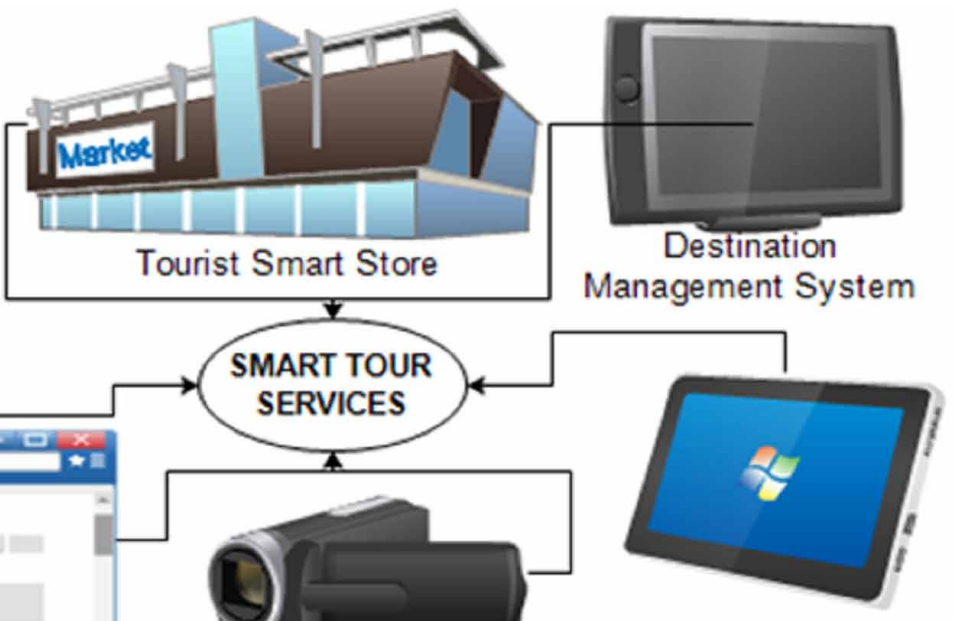

Smart Tour Guide

\section{Smart Site Security}

(Dissanayakelage, 2013). This is largely so because, tourism deals first with sighting. People want to see in advance what they are coming to see at the sites. They want to have a virtual view and simulated experience of the tour locations. This helps build strong eagerness and enthusiasm in their minds if the impressions created by the web programs are winning. The goal of a user-centered website for tourism in Africa is to present contents based on the personas modelling paradigm. Typical tourism promoting websites depicted in Figure 6 must be search engine optimized (SEO), allow campaigns through banner ads, word-of-mouth, offline promotion and support customer-relationship management (CRM). The CRM subsystem must allow feedbacks; give room for forum interaction and reviews. Two major factors are needed to define the web in this regard - mobility and interactivity. Tour websites must be accessible on mobile devices and must provide smart interactivity to the users.

\subsection{Social Media Adoption}

The social media has become a household name in almost all countries of the world. Even the remotest suburbs now enjoy the advantage of social networks in building relationships, creating career opportunities, fostering communications, and creating awareness or advocacy for a product or service. As the social networks expand, new media and new features are being developed to meet users' ever-increasing communication needs. Africans boast of a wide social network and their ability to efficiently use the digital services and tools made available by the technological advances in the continent (Efiong \& Aranuwa, 2017). The tourism business in Africa can leverage on the social platforms such as Facebook, twitter, Instagram, Whatsapp, etc. for adverts placement, promotion and as feedback channels.

\section{BENEFITS OF LEVERAGING ON ICT FOR TOURISM PROMOTION IN AFRICA}

There are immeasurable benefits derivable from ICT application in tourism. These have been greatly explored by several scholars. Bethapudi (2015) informed that ICT has restructured the tourism industry in India by re-engineering its products and services and their delivery. Dissanayakelage 


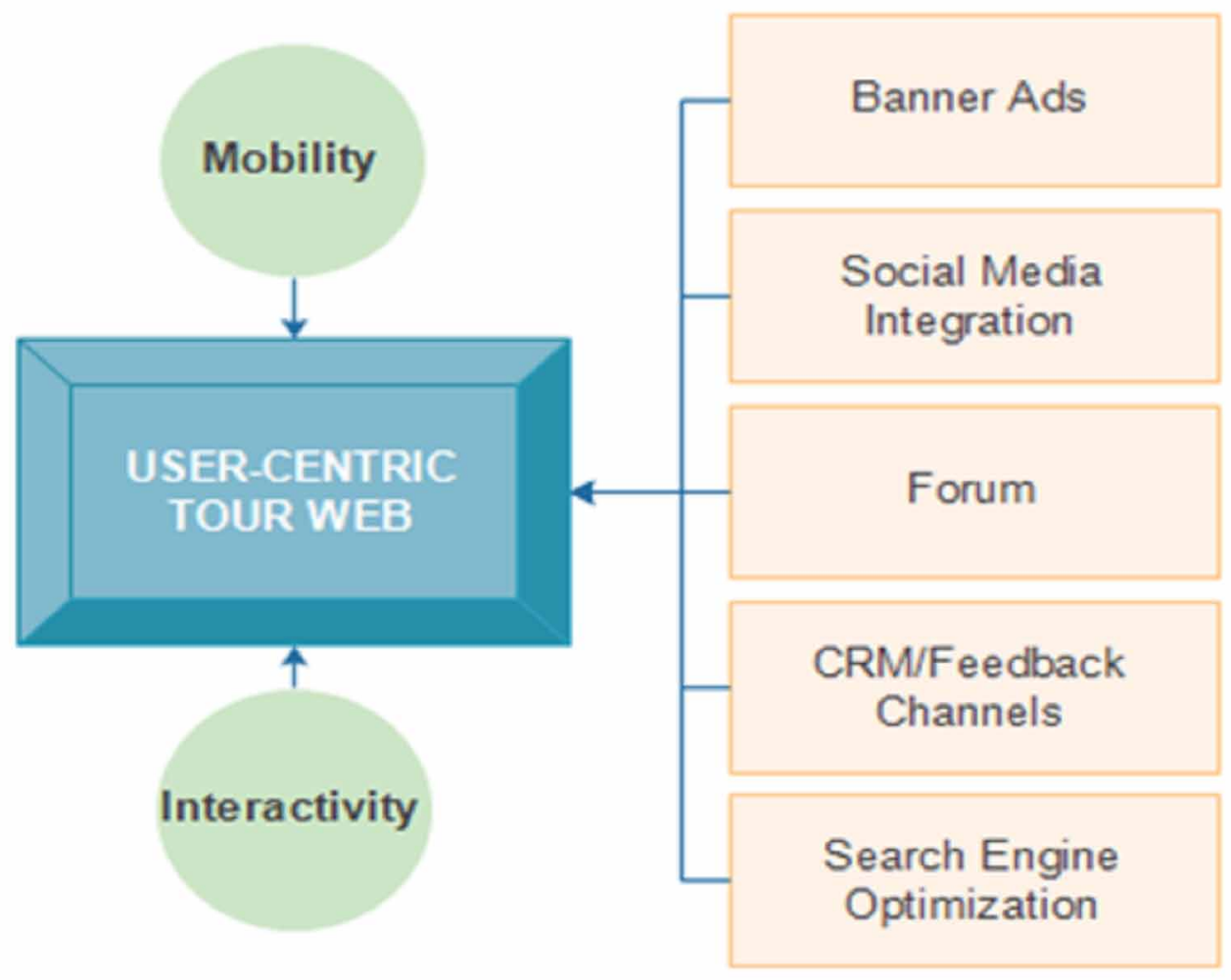

(2013) describes ICT's role in tours and travels as smart tourism with the propensity to promote destinations and enhance experience of visitors. Similar reports have been discussed by the researchers in (Buhalis \& Amaranggana, 2014; Gretzel, Zhong \& Chulmo, 2016). By leveraging on ICT, the African continent will substantially make gains in the following areas and more.

1. Increased Visibility: With effective policy implementation, ICTs have the potentials to help develop and expose the treasures of Africa to the rest of the world.

2. Increased Traffic: Increased visibility of the tourism features in Africa will result in generating multiple customers' interest in visiting the different sites in the continent.

3. Increased GDP: With aroused and sustained interest of the customers and their actual patronage, the economic states of the respective countries will definitely shift towards positive figures. This is a key trick adopted by the developed nations that have attained great scales in the world's tourism matrix.

4. Increased Employment Opportunities: The tourism industry in Africa can be a big employer if the structure is fully developed and the potentials harvested. This will not only burn down greatly the unemployment ladder but also equip the people with resources to develop themselves and their immediate society.

5. Reduced Negative Image: One of the best ways to change a bad image is to present a new, better image. Until the positive things in Africa are presented to the globe, the negative worldview of the continent may not be changed easily. We can use ICT as a tool to change people' perception of our people by showing them the goodness in the land. By visiting the continent for tourism, 
the world will begin to know how great the people are in arts and culture, religion, science and technology, sociology, etc.

\section{CONCLUSION}

The future of the African tourism sector is promising. The potentials are there as well as the market for tourism. In Africa, we have the natural attraction centres and other sites of natural blessings; we have the population and the human resources to grow tourism. The rest of the world would choose Africa as destination of choice for tourism and leisure if the potentials are fully harnessed. In addition to this, we will need to pay more attention to tourism infrastructure, policies and facilities to support the existing natural and human resources in the continent. We would achieve this by adopting appropriate digital tools and leveraging effectively and efficiently on their services for tourism promotion, service delivery, and after-service needs.

This paper has explored the avenues of tourism promotion in Africa in the 21st century by leveraging on digital technologies. We conclude that computing technologies have gained a place of residence in Africa and will keep expanding rapidly within the next few years. As they affect other areas of our endeavours with positive results, they have huge potentials to push tourism for a greater GDP. The possibility of this has been discussed in the study. The ideas of smart tourism and digital marketing have been presented as may be applied in the African tours and travels industry for spontaneous economic advancement. The digital tools and their benefits to tourism in Africa as discussed in the paper will determine the future of tourism in the continent.

The implications of this digital advantage for Africa are multifaceted: the continent will harness its tourism potentials and generate substantial income from its activities. It is expected that it will create more employment opportunities for the teaming African youths at home and in the diaspora. This will ultimately cut down on poverty that usually leads to social vices such as vandalism, hooligalism, armed robbery etc. as more youths would be usefully engaged. It will also change the negative image the world may have of the black race and give it an international and cross-cultural advantage.

However, the paper submits that the ICT and its tools will make no difference in the African tourism sector if not used in the most efficient and effective ways. For successful implementation and adoption of ICT, adequate steps must therefore, be taken to ensure the best results are realized. In practice, we recommend that the tourism management systems should be designed as a marketing strategy. This means designing them as a selling point to the public. Such systems should adopt the principles of recommender systems by leveraging on user profiling based on the persona model. Tourist systems developers must employ appropriate machine learning algorithms for the user profiling system while the contents developers should ensure search engine optimization of all web contents (Vila et al., 2018). Of course, contents written should be timely and relevant and only the positive images of the destination should be made public. There is also a need to develop social media campaigns by building enticing components of the social networks to allow robust interactions. All of these should be done in a way that allows users to navigate with ease and make the most use of the contents. 


\section{REFERENCES}

Bethapudi, A. (2015). Role of ICT in Promoting a Rural Tourism Product. Journal of Tourism \& Hospitality, 4(3), 154-156. doi:10.4172/2167-0269.1000154

Buhalis, D., \& Amaranggana, A. (2014). Smart Tourism Destinations. In Z. Xiang \& I. Tussyadiah (Eds.), Information and Communication Technologies in Tourism (pp. 553-564). Heidelberg: Springer.

Contents Marketing Software (CMS). (2018). Retrieved from http://fliphtml5.com

Dissanayakelage, P. N. (2013, June 2). Smart Tourism as a Tool for Destination Promotion and Enhance Traveler Experience. Sri Lanka Tourism Development Authority 2013. http://www.srilanka.travel/

Efiong, J. E., \& Aranuwa, F. O. (2017). Mobile Devices' Features and Usability: The Nigerian Utilization Experience. International Journal of Computer Trends and Technology, 48(4), 200-207. http://www.ijcttjournal. org. doi:10.14445/22312803/IJCTT-V48P137

Fayissa, B., Nsiah, C., \& Tadasse, B. (2007). The impact of tourism on economic growth and development in Africa. Tourism Economics, (September). doi:10.5367/000000008786440229

Godwin, K. (2009). Designing for the Digital Age. Wiley Publishing, Inc.

Gretzel, U., Sigala, M., Xiang, Z., \& Koo, C. (2015). Smart Tourism: Foundations and Developments, Electron Markets. Institute of Information Management, University of St. Gallen. doi:10.1007/s12525-015-0196-8

Gretzel, U., Zhong, L., \& Chulmo, K. (2016). Application of smart tourism to cities. International Journal of Tourism Cities, 2(2), IJTC-04-2016-0007. doi:10.1108/IJTC-04-2016-0007

Guo, Y., Liu, H., \& Chai, Y. (2014). The embedding convergence of smart cities and tourism internet of things in China: An advance perspective. Advances in Hospitality and Tourism Research, 2(1), 54-69.

Iain, C., Fernandes, E., Messerli, H., \& Twining-Ward, L. (2016) Tourism in Africa: The World Bank Harnessing Tourism for Growth and Improved Livelihoods. World Bank. Retrieved from www.worldbank.org/afr/tourism

Itumo, V. N. (2017). Nigeria's Economic Growth through Tourism Promotion/Sustainability: Perspective, Opinion and Commentary. SEA Practical Application of Science, 14(5), 231-236.

Jacob, A. (2018). Digital Marketing In The Travel \& Tourism Industry. Retrieved from https://www.tahawal. com/blog/digital-marketing-tourism-travel

Jasrotia, A., \& Gangotia, A. (2018). Smart Cities to Smart Tourism Destinations: A Review Paper. Journal of Tourism Intelligence and Smartness, 1(1), 47-56.

Koo, C., Gretzel, U., Hunter, W. C., \& Chung, N. (2015). The role of IT in Tourism. Asia Pacific Journal of Information Systems, 25(1), 99-104. doi:10.14329/apjis.2015.25.1.099

Li, Y., Hu, C., Huang, C., \& Duan, L. (2017). The Concept of Smart Tourism in the Context of Tourism Information Services. Tourism Management, 58(1), 293-300. doi:10.1016/j.tourman.2016.03.014

Martín, J. M., Fernández, J. A. S., Martín, J. A. R., \& Aguilera, J. D. J. (2017). Assessment of the Tourism's Potential as a Sustainable Development Instrument in Terms of Annual Stability: Application to Spanish Rural Destinations in Process of Consolidation. Sustainability, 1692(9). doi:10.3390/su9101692

Mazier, G. (2017). Four Ways Marketers Promote Places Using Digital Tools. Forbes. Retrieved from https:// www.forbes.com/sites/forbesagencycouncil/2017/05/17/four-ways-marketers-promote-places-using-digitaltools/\#15d255ed7c02

Nielsen, L. (2013). Personas. In M. Soegaard \& R. F. Dam (Eds.), The Encyclopedia of Human-Computer Interaction (2nd ed.). Aarhus, Denmark: The Interaction Design Foundation. Retrieved from http://www. interaction-design.org/encyclopedia/personas.html

Pruitt, J., \& Adlin, T. (2006). The Persona Lifecycle: Keeping People in Mind Throughout Product Design. Morgan Kaufmann, 2006. 
United Nations World Tourism Organization (UNWTO). (2017). Digital Marketing in Tourism. Tourism Leadership Programme Programme hosted \& sponsored by The Ministry of Economy of the United Arab Emirates.

Vila, T. D., Vila, N. A., González, E. A., \& Jose, A. F. B. (2018). The Role of the Internet as a Tool to Search for Tourist Information. Journal of Global Information Management, 26(1), 58-84. doi:10.4018/JGIM.2018010104

Wang, D., Park, S., \& Fesenmaier, D. (2012). The role of smartphones in mediating the tourism experience. Journal of Travel Research, 51(4), 371-387. doi:10.1177/0047287511426341

World Bank. (2013). Africa's Tourism Set to Boost Economic Growth, Create New Jobs, and Now Outpace Other Regions for New Tourism Investment. The World Bank Group. Retrieved from http://www.worldbank.org/en/ news/press-release/2013/10/03/africa-tourism-economic-growth-new-jobs-tourism-investment

World Bank - Africa Finance and Private Sector Development (AFTFP). (2011). Africa Tourism Strategy: Transformation through Tourism. Washington, DC: World Bank.

World Travel and Tourism Council (WTTC). (2013). Travel \& Tourism Economic Impact 2013, Sub Saharan Africa. London, UK: WTTC.

John E. Efiong is a Lecturer with the Department of Computer Science, Wesley University, Ondo City, Ondo, Nigeria. His research interest covers mobile learning, ubiquitous computing, human computer interaction and software engineering. He has a rich knowledge of information technology applications and adoption in theology and cyberevangelism.

Adewale Adegbola is an interdisciplinary researcher, with strong interest in chemistry/biochemistry, hospitality management and eco-tourism. He is a member of faculty in Wesley University, Ondo. 